\title{
PENGARUH AKUNTABILITAS, PARTISIPASI DAN PENGAWASAN TERHADAP KINERJA ANGGARAN BERKONSEP VALUE FOR MONEY PADA BADAN PENGELOLAAN KEUANGAN DAN ASET DAERAH KABUPATEN BENGKALIS
}

\author{
Zakaria Batubara, Ria Risna \\ Sekolah Tinggi Ilmu Ekonomi (STIE) Syariah Bengkalis \\ zakariabb@gmail.com, ria.risna1@gmail.com \\ https://doi.org/10.46367/jas.v4i1.221
}

Received: Mei 11, 2020 Revised: Jun 02, 2020 Accepted: Jun 16, 2020 Published: Jun 25, 2020

\begin{abstract}
The purpose of this research was to determine partially and simultaneously the influence of accountability, public participation and supervision of budget performance with the concept of value for money in the Bengkalis District Financial and Asset Management Agency. This research uses descriptive quantitative analysis method. The sampling technique uses boring sampling method. The data analysis technique used is multiple linear of regression. The results showed that partial accountability, participation and supervision had a positive and significant effect on budget performance with the concept of value for money in the Bengkalis District Financial and Asset Management Agency. While simultaneously accountability, participation and supervision have a positive and significant effect on budget performance with the concept of value for money in the Regional Financial and Asset Management Agency in Bengkalis Regency with a $93.5 \%$ influence.
\end{abstract}

Keywords: Accountability, Participation, Oversight, Budget Performance, Value for Money.

\begin{abstract}
ABSTRAK
Tujuan penelitian ini adalah untuk mengetahui secara parsial dan simultan pengaruh akuntabilitas, partisipasi masyarakat dan pengawasan terhadap kinerja anggaran dengan konsep value for money pada Badan Pengelolaan Keuangan dan Aset Daerah Kabupaten Bengkalis. Penelitian ini menggunakan metode deskriptif analisis kuantitatif. Teknik pengambilan sampel menggunakan metode boring sampling. Teknik analisa data yang digunakan yaitu regresi linier berganda. Hasil penelitian menunjukkan bahwa secara parsial akuntabilitas, partisipasi dan pengawasan berpengaruh positif dan signifikan terhadap kinerja anggaran dengan konsep value for money pada Badan Pengelolaan Keuangan dan Aset Daerah Kabupaten Bengkalis. Sedangkan secara simultan akuntabilitas, partisipasi dan pengawasan berpengaruh positif dan signifikan terhadap kinerja anggaran dengan konsep value for money pada Badan Pengelolaan Keuangan dan Aset Daerah Kabupaten Bengkalis dengan besar pengaruh 93,5\%.
\end{abstract}

Kata kunci: Akuntabilitas, Partisipasi, Pengawasan, Kinerja Anggaran, Value for Money. 


\section{PENDAHULUAN}

Perkembangan paradigma pemerintahan, diberbagai negara yang bergeser dan berproses dari rulling government, menuju kearah governance dan penciptaan administrasi pemerintah yang berhasil guna, berdaya guna, dan berkeadilan telah membuka kesadaran bagi setiap orang, terutama aparat pemerintah untuk senantiasa tanggap akan tuntutan lingkungannya, dengan berupaya memberikan pelayanan yang terbaik, secara transparan dan berakuntabilitas (Bastian 2001, 1).

Dalam waktu yang relatif singkat akuntansi sektor publik telah mengalami perkembangan yang sangat pesat. Saat ini terdapat perhatian yang lebih besar terhadap praktik akuntansi yang dilakukan oleh lembaga-lembaga pemerintah, perusahaan milik negara atau daerah, dan berbagai organisasi publik lainnya dibandingkan dengan masa-masa sebelumnya. Terdapat tuntutan yang lebih besar dari masyarakat untuk dilakukan transparansi dan akuntabilitas publik oleh lembaga-lembaga sektor publik.

Dalam pemerintahan sendiri, sudah mulai ada perhatian yang lebih besar terhadap penilaian kelayakan praktik manajemen pemerintahan yang mencakup perlunya dilakukan perbaikan sistem akuntansi manajemen, sistem akuntansi keuangan, perencanaan keuangan dan pembangunan, sistem pengawasan dan pemeriksaan, serta berbagai implikasi finansial atas kebijakan-kebijakan yang dilakukan pemerintah. Jika diamati secara lebih mendalam akuntansi sektor publik memiliki peranan yang vital dan menjadi subyek untuk didiskusikan baik dari kalangan akademisi maupun praktisi sektor publik.

Organisasi sektor publik saat ini tengah menghadapi tekanan untuk lebih efisien, memperhitungkan biaya ekonomi dan biaya sosial, serta dampak negatif atas aktivitas yang dilakukan. Berbagai tuntutan tersebut menyebabkan akuntansi dapat dengan cepat diterima dan diakui sebagai ilmu yang dibutuhkan untuk mengelola urusan-urusan publik. Akuntansi sektor publik pada awalnya merupakan aktivitas yang terspesialisasi dari suatu profesi yang relatif kecil. Namun demikian, saat ini akuntansi sektor publik sedang mengalami proses untuk menjadi disiplin ilmu yang lebih dibutuhkan dan substansial keberadaannya (Mardiasmo 2002, 1).

Anggapan bahwa lembaga sektor publik telah mengalami kebangkrutan dibanyak negara terutama negara-negara berkembang, tidak sepenuhnya benar. Memang tidak dapat disangkal bahwa kinerja sektor publik dinilai buruk, akan tetapi hal tersebut tidak dialami oleh semua negara berkembang. Negara seperti Korea Selatan, Taiwan, Malaysia, dan Thailand memiliki pelayanan publik dan perusahaan-perusahaan publik yang baik kinerjanya yang dapat meberikan kontribusi yang besar terhadap pembangunan nasional dan stabilitas publik.

Dalam dua dasawarsa terakhir telah terjadi perkembangan (akuntansi) sektor publik yang pesat. Istilah "akuntabilitas publik, value for money, reformasi sektor publik, privatisasi, good public governance," telah begitu cepat masuk ke dalam kamus sektor publik isu yang muncul dalam sektor publik merupakan suatu rangkaian yang akarnya merupakan tuntutan diciptakannya good publik and corporate governance. Isu tersebut kemudian diikuti dengan munculnya isu-isu baru, misalnya tuntutan dilakukan reformasi sektor publik yang diorientasikan 
pada pembentukan organisasi sektor publik yang ekonomis, efisien, efektif, transparan, responsif, dan memiliki akuntabilitas publik yang tinggi.

Munculnya isu perlunya dilakukan reformasi akuntansi, auditing, sistem manajemen keuangan publik, privatisasi perusahaan-perusahaan publik, dan tuntutan dibuatnya laporan keuangan eksternal merupakan percabangan dari isu besar dalam sektor publik (Mardiasmo 2002, 15-17).

Badan Pengelolaan Keuangan dan Aset Daerah Kabupaten Bengkalis (BPKAD) baru terbentuk pada tahun 2017 berdasarkan Peraturan Daerah Kabupaten Bengkalis Nomor 3 Tahun 2016 tentang Pembentukan dan Susunan Perangkat Daerah yang kemudian dijabarkan melalui Peraturan Bupati Bengkalis Nomor 61 Tahun 2016 tentang Kedudukan, Susunan Organisasi, Tugas, Fungsi, dan Uraian Tugas serta Tata Kerja pada Badan Pengelolaan Keuangan dan Aset Daerah Kabupaten Bengkalis. Badan Pengelolaan Keuangan dan Aset Daerah Kabupaten Bengkalis (BPKAD) sendiri merupakan penggabungan 2 (dua) unit kerja pada Sekretariat Daerah yaitu Bagian Keuangan dan Bagian Perlengkapan yang melebur membentuk Satuan Organisasi Perangkat Daerah (SOPD) sesuai amanat Peraturan Pemerintah Nomor 18 tahun 2016 tentang Organisasi Perangkat Daerah. Struktur organisasi Badan Pengelolaan Keuangan dan Aset Daerah Kabupaten Bengkalis (BPKAD) terbentuk dari penggabungan fungsi Bagian Keuangan Sekretariat Daerah dan Bagian Perlengkapan Sekretariat Daerah Kabupaten Bengkalis. Badan Pengelolaan Keuangan dan Aset Daerah Kabupaten Bengkalis (BPKAD) selain berfungsi sebagai pengelolaan keuangan daerah yang meliputi penganggaran, penatausahaan, akuntansi, pelaporan dan pertanggungjawaban keuangan daerah juga berfungsi sebagai Bendahara Umum Daerah, sebagaimana diatur dalam Peraturan Pemerintah Nomor 58 tahun 2005 tentang Pengelolaan Keuangan Daerah (BPKAD 2016).

Adapun fenomena yang terjadi Kinerja Pemerintah akhir-akhir ini menjadi sorotan masyarakat khususnya dalam pengelolaan dana publik. Pada tahun 2016 mantan Bupati Bengkalis periode 2010 - 2015 ditahan karena diduga ikut menikmati uang haram dana hibah dan bantuan sosial (bansos) Kabupaten Bengkalis sebesar Rp. 272 miliar pada tahun anggaran 2012. Kasus korupsi bansos Bengkalis yang merugikan uang rakyat hingga Rp. 272 miliar ini telah menyebabkan mantan Ketua DPRD Bengkalis divonis 8 tahun penjara. Terungkap aliran dana korupsi yang diduga dilakukan sejumlah anggota DPRD dan beberapa pejabat penting yang ada di Pemkab Bengkalis mengalir ke anggota DPRD dari partai PAN yang sekarang ketua baru dikantor wakil rakyat DPRD Kabupaten Bengkalis (Tanjung 2018).

Badan Pengelolaan Keuangan dan Aset Daerah (BPKAD) Kabupaten Bengkalis sendiri Pengelolaan Anggaran Pendapatan Belanja Daerah (APBD) belum tepat sasaran sehingga Anggaran Pendapatan Belanja Daerah (APBD) kabupaten Bengkalis mengalami defisit. Pada tahun 2015 mengalami defisit sebesar 2.106.353.095.212. Tahun 2016 mengalami defisit sebesar 266.720.063.978 dan pada tahun 2017 sebesar 9.909.227.210 hingga menyebabkan banyaknya tunda bayar berakibat gaji dan tidak bisa sepenuhnya dibayar.

BPKAD sendiri masih kurangnya partisipasi masyarakat, partisipasi masyarakat merupakan kunci sukses dari pelaksanaan otonomi daerah karena 
dalam partisipasi menyangkut aspek pengawasan dan aspirasi. Partisipasi masyarakat mempertinggi fungsi pengawasan yang dilakukan dewan.

Akuntabilitas di BPKAD sendiri belum berjalan dengan baik, karena belum bisa memberikan pertanggungjawaban, menyajikan, melaporkan, dan mengungkapkan segala aktifitas dan kegiatan kepada masyarakat. fungsi sebagaimana mestinya.

Dalam konteks otonomi daerah value for money merupakan jambatan untuk mengantarkan pemerintah daerah mencapai good governance. Value for money tersebut harus dioperasionalkan dalam pengelolaan keuangan daerah dan anggaran daerah. Untuk mendukung dilakukannya pengelolaan dana publik yang berdasarkan konsep value for money, maka diperlukan Sistem Pengelolaan Keuangan Daerah dan Anggaran Daerah yang baik. Hal tersebut dapat tercapai apabila pemerintah daerah memiliki sistem akuntansi yang baik (Mardiasmo 2004). Oleh sebab itu tujuan penelitian ini adalah untuk mengetahui pengaruh akuntabilitas, partisipasi masyarakat dan pengawasan secara parsial dan simultan terhadap kinerja anggaran dengan konsep value for money pada Badan Pengelolaan Keuangan dan Aset Daerah Kabupaten Bengkalis.

\section{TELAAH LITERATUR}

\section{Konsep Akuntabilitas Publik}

Akuntabilitas (accountability) secara harfiah dapat dirtikan sebagai "pertanggungjawaban". Mempertanggungjawabkan keberasilan dan kegagalan kepada yang mendelegasikan kewenangan dan mereka puas terhadap kinerja pelaksanaan kegiatannya. Akuntabilitas adalah kewajiban untuk memberikan pertanggungjawaban atau untuk menjawab dan menerangkan kinerja dan tindakan seseorang/badan hukum/pimpinan kolektif suatu organisasi kepada pihak yang memiliki hak atau kewenangan untuk meminta keterangan atau pertanggungjawaban (Asrida 2012).

Suatu entitas (organisasi) yang accountable adalah entitas yang mampu menyajikan informasi secara terbuka mengenai keputusan-keputusan yang telah diambil selama beroperasinya entitas tersebut memungkinkan pihak luar (misalnya legislatif, auditor, atau masyarakat secara luas), mereview informasi tersebut, serta bila dibutuhkan harus ada kesediaan untuk mengambil tindakan korektif. Dengan demikian penggunaan istilah akuntabilitas publik mengandung makna yang jelas bahwa hasil-hasil operasi tersebut didalamnya keputusankeputusan dan kebijakan yang diambil atau yang dianut oleh suatu entitas harus dapat dijelaskan dan dipertanggungjawabkan kepada publik (masyarakat) dan masyarakat harus pada posisi untuk dapat mengakses informasi tersebut (Ulum 2004, 38).

Accountability for probility berkaitan dengan penghindaran terhadap kejahatan jabatan khususnya untuk meyakinkan bahwa dana telah digunakan dengan benar dan dengan cara yang benar. Accountability for legality menekankan bahwa kekuasaan yang diberikan oleh undang-undang tidak melampaui batas. Prosess accountability berkaitan dengan apakah terdapat prosedur-prosedur yang memadai yang diterapkan untuk melaksanakan aktivitasaktivitas tertentu, serta untuk meyakinkan apakah aktivitas-aktivitas tertentu dilakukan sesuai dengan yang telah ditetapkan sebelumnya. Performance, 
programme, policy accountability berturut-turut menekankan pada kinerja, program, dan kebijakan dari suatu entitas yang disampaikan publik.

Akuntabilitas juga menyangkut fungsi pengawasan maka informasi yang disajikan kepada publik tersebut harus memungkinkan untuk dapat diaudit oleh aparat pengawasan fungsional. Dalam kaitan ini akuntansi pemerintah sebagai penyedia informasi (terutama yang bersifat keuangan) dari aktivitas penggunaan resources oleh entitas pemerintah (sektor publik) memegang peranan yang sangat signifikan. Karena tujuan akuntansi (pelaporan keungan) sering kali diturunkan dari tujuan entitas, maka tujuan peningkatan kesejahteraan masyarakat merupakan landasan pelaksanaan akuntansi pemerintah (Ulum 2004, 40).

\section{Konsep Partisipasi Masyarakat}

Sejak dekade 1990-an dan sejak era reformasi di Indonesia, telah terjadi pergeseran cara pandang yang mewarnai debat dalam studi tata pemerintahan dan pembangunan. Dalam konteks pembangunan muncul wacana "pembangunan partipatoris" yang mengusung partisipasi maupun keterlibatan kaum marginal dan perempuan dalam perumusan kebijakan. Di lini pemerintahan berkembang pula wacana kewargaan (citizenship) dan good governance yang kian memperkuat agenda desentralisasi dan demokrasi. Pada saat yang sama pertautan antara partisipasi dan good governance melahirkan semangat baru partisipasi warga. Dibentuk oleh gerakan paralel antara hak asasi dan pemikiran pembangunan, partisipasi warga dikerangkai ulang dan bahkan diyakini sebagai hak fundamental manusia dan waraga, sekaligus sebagai prasyarat bagi pembentukan hak-hak lainnya (Eko 2005, 91).

Partisipasi adalah kosakata yang sudah lama menghiasi bibir para pejabat dan lembaran-lembaran kebijakan pembangunan di Indonesia. Para pejabat mulai dari presiden hingga kepala desa selalu berujar bahwa pembangunan tidak akan berhasil bila tidak didukung oleh partisipasi masyarakat, terutama partisipasi membayar pajak. Partisipasi sebagai mobilisasi, kalau butuh dukungan (material dan fisik), perintah selalu menggunakan pendekatan mobilisasi, yang juga diyakini sebagai partisipasi. Contohnya kita selalu melihat dan mendengar mobilisasi "partisipasi masyarakat membayar pajak merupakan kunci keberhasilan pelaksanaan otonomi daerah" (Eko 2005, 95).

Partisipasi dipahami sebagai bentuk dukungan masyarakat. Pemerintah dan parlemen yakin betul bahwa mereka memegang kekuasaan (jabatan) karena memperoleh mandat dan kepercayaan diri masyarakat melalui proses pemilihan umum (Eko 2005, 96). Partisipasi dipahami dan dipraktikkan sebagai bentuk sosialisasi kebijakan pemerintah kepada masyarakat. Dalam kontek kebijakan, pemerintah merasa perlu melakukan sosialisasi kepada masyarakat, untuk memberi tahu sebelum kebijakan dilaksanakan agar tidak terjadi gejolak dalam masyarakat. Dalam proses sosialisasi yang terjadi semacam komunikasi monolog.

Partisipasi dipahami dalam pengertian nominal, yakni menjatuhkan pilihan (vote), bukan dalam pengertian substantif, yakni menyampaikan suara. Sering muncul argumen bahwa partisipasi secara langsung dengan melibatkan seluruh warga masyarakat tidak bakal terjadi, sehingga membutuhkan pemimpin dan dan wakil rakyat yang dipilih melalui pemilihan umum secara berkala. Partisipasi cendrung dipahami dalam kerangka formal-prosedural. Kalau sudah 
ada pemilihan dan lembaga perwakilan tampaknya dianggap sudah ada partisipasi (Eko 2005, 97).

Jebakan tirani partisipasi, yang sering terjadi disektor pejuang masyarakat. Mereka yang sangat romantis kepada masyarakat mengatakan bahwa partisipasi adalah segala-galanya dalam pemerintahan dan pembangunan. Adalah kata rakyat itulah yang terbaik, karena rakyat tidak berbuat salah. Semuanya harus ditentukan secara partisipatif, sehingga terkesan menihilkan otoritas pemerintah dan representasi wakil rakyat yang diberi mandat oleh rakyat. Distorsi dan manipulasi dalam perencanaan pembangunan partisipatif dari bawah. Sampai sekarang Indonesia memang mengenal perencanaan pembangunan dari bawah, yang dimulai dari Musbagdes didesa sampai Rakorbang dikabupaten/kota (Eko 2005, 98).

Partisipasi/participation adalah setiap warga negara mempunyai suara dalam pembuatan keputusan, baik secara langsung maupun melaui intermediasi institusi legitimasi yang mewakili kepentingannya. Partisipasi seperti ini dibangun atas dasar kebebasan berasosiasi dan berbicara, serta berpartisipasi secara kontruksi. Partisipasi dapat dikatagorikan dengan kalimat "turut ambil bagian" berpartisipasi dalam pengambilan keputusan yang bersifat demokratis, pengakuan hak asasi manusia, kebebasan dalam mengemukakan pendapat, kebebasan pers dan mengakomodasi atau menampung aspirasi masyarakat (Ulum 2004, 31).

Partisipasi bermaksud untuk menjamin agar setiap kebijakan yang diambil mencerminkan aspirasi masyarakat. Dalam rangka mengantisipasi berbagai isu yang ada, pemerintah daerah menyediakan saluran komunikasi agar masyarakat dapat mengutarakan pendapatnya. Jalur komunikasi ini meliputi pertemuan umum, tamu wicara, konsultasi, dan penyampaian pendapat secara tertulis. Bentuk lain untuk merangsang keteribatan masyarakat adalah melalui perencanaan partisipatif untuk menyiapkan agenda pembangunan, pemantauan, evaluasi dan pengawasan secara partisipatif dan mekanisme konsultasi untuk menyelesaikan isu sektoral. Instrumen dasar partisipasi adalah pengaturan yang menjamin hak untuk menyampaikan pendapat dalam proses pengambilan keputusan, sedangkan intrumen-instrumen pendukung adalah pedoman-pedoman pemerintahan partisipatif yang mengakomodasi hak penyampaian pendapat dalam segara proses perumusan kebijakan dan peraturan, proses penyusunan strategi pembangunan, tata ruang, program pembangunan, penganggaran, pengadaan, dan pemantauan (Dwiyanto 2005, 15).

\section{Konsep Pengawasan}

Pengawasan (control) adalah suatu proses kegiatan yang dilakukan secara terus menerus atau berkesinambungan untuk mengamati, memahami, dan menilai setiap pelaksanaan kegiatan tertentu sehingga dapat dicegah atau diperbaiki kesalahan atau penyimpangan yang terjadi. Pengawasan adalah proses untuk memastikan bahwa kegiatan yang direncanakan dapat dilaksanakan dengan baik. Pada tahap perencanaan ditetapkan indikator dan target kinerja. Sepanjang pelaksanaan kegiatan, aparatur pengawasan menilai sejauh mana aktivitas dilaksanakan dengan baik target knerja tercapai. Aparatur pengawas juga menilai apakah ketentuan perundang-undangan yang terkait dengan pelaksanaan kegiatan dipatuhi. Aparatur pengawasan memberikan informasi umpan balik tentang 
tindakan yang perlu dilakukan apabila terhadap penyimpangan terhadap target. Umpan balik diperlukan untuk melanjutkan pelaksanaan kegiatan yang sedang berjalan atau untuk pelaksanaan kegiatan berikutnya (Siregar 2015, 60).

Pengawasan merupakan sebagai proses pemantauan kinerja karyawan berdasarkan standar untuk mengukur kinerja, memastikan kualitas atas penilaian kinerja dan pengambilan informasi yang dapat dijadikan umpan balik pencapaian hasil yang dikomunikasikan ke para karyawan (Pertiwi 2015).

Pengawasan keuangan negara adalah segala tindakan untuk menjamin agar pengelolaan keuangan negara berjalan sesuai dengan tujuan, rencana, aturanaturan yang telah digariskan (Ulum 2009, 129).

\section{Konsep Kinerja Anggaran}

Kinerja adalah gambaran tentang pencapaian pelaksanaan suatu kegiatan atau program atau kebijakan dalam mewujudkan visi, misi, tujuan dan sasaran organisasi. Dalam bahasa yang sederhana, kinerja adalah "prestasi kerja". Kinerja dapat pula diartikan sebagai hasil kerja dari seseorang atau kelompok orang dalam organisasi (Rudianto 2013, 186).

Kinerja merupakan sebuah istilah yang mempunyai banyak arti. Kinerja bisa berfokus pada input, misalnya uang, staf/karyawan, wewenang yang legal, dukungan politis atau birokrasi. Kinerja bisa juga berfokus pada aktivitas atau proses yang mengubah input menjadi output kemudian menjadi outcome, misalnya kesesuaian program atau aktivitas dengan hukum, peraturan, dan pedoman yang berlaku, atau standar proses yang telah ditetapkan. Saat sekarang dalam upaya mengembangkan manajemen yang berdasarkan kinerja, kinerja sering kali difokuskan pada kualitas jasa dan outcome sebagai hasil yang dicapai oleh individu, organisasi atau populasi diluar organisasi yang menjadi sasaran program atau kegiatan. Kinerja sering kali juga berfokus pada intermediate outcomes seperti kepuasan klien atau perubahan individu atau organisasi dalam jangka pendek (Ulum 2009, 19).

Anggaran merupakan pernyataan mengenai estimasi kinerja yang hendak dicapai selama periode waktu tertentu yang dinyatakan dalam ukuran finansial (Mardiasmo 2002, 61). Banyak orang mengasosiasi kata anggaran terutama dengan pembatasan pengeluaran. Manajemen sering kali memberikan setiap unit dalam suatu organisasi anggaran pengeluaran dan kemudian mengharapkannya tetap berada dalam batasan yang disebutkan oleh anggaran (Horngren et al. 2016, 285). Anggaran merupakan pernyataan mengenai estimasi kinerja yang hendak dicapai selama periode waktu tertentu yang dinyatakan dalam ukuran finansial, sedangkan penganggaran adalah proses atau metoda untuk mempersiapkan suatu anggaran (Mardiasmo 2002, 6).

Menurut National Committee on Govermental Accounting (NCGA) yang saat ini telah menjadi Govermental Accounting Standart Board (GASB) definisi anggaran adalah: Rencana operasi keuangan, yang mencakup estimasi pengeluaran yang diusulkan, dan sumber pendapatan yang diharapkan untuk membiayainya dalam priode waktu tertentu (Bastian 2001, 164). Anggaran adalah laporan-laporan formal sumber daya-sumber daya keuangan yang disisihkan untuk melaksanakan kegiatan-kegiatan tertentu selama priode waktu yang ditetapkan (Handoko 2009, 377). 
Kinerja anggaran adalah alat atau instrumen yang dipakai oleh DPRD untuk mengevaluasi kinerja kepala daerah. Alat itu berupa strategi makro dan policy yang tertuang dalam Propeda dab Renstrada, Arah dan Kebijakan Umum APBD serta strategi dan prioritas APBD (Mardiasmo 2004, 219). Anggaran pemerintah merupakan pedoman bagi segala tindakan yang akan dilaksanakan dan di dalam anggaran disajikan rencana-rencana penerimaan dan pengeluaran dalam satuan rupiah yang disusun menurut klasifikasinya secara sistematis. Jumlah penerimaan dan pengeluaran yang diharapkan dapat dicapai dalam tahun anggaran tertentu, pada hakikatnya menggambarkan kegiatan-kegiatan yang dilaksanakan oleh aparat-aparat pemerintah bersama-sama rakyat (Sabeni dan Imam 2008, 39).

\section{Konsep Value For Money}

Value for Money merupakan prinsip pengelolaan organisasi sektor publik yang mendasar pada tiga elemen utama yaitu: ekonomi, efisiensi, dan efektivitas. Value for Money dapat tercapai apabila organisasi telah menggunakan biaya input paling kecil untuk mencapai output yang optimum dalam rangka mencapai tujuan organisasi (Iswahyudi et al. 2016).

Sektor publik sering dinilai sebagai sarang inefisiensi, pemborosan, sumber kebocoran dana, dan institusi yang selalu merugi tuntutan baru muncul agar organisasi sektor publik memperhatikan Value For Money dalam menjalankan aktifitasnya. Value For Money merupakan konsep pengelolaan organisasi sektor publik yang mendasarkan pada tiga elemen utama, yaitu ekonomi, efisiensi, dan efektivitas. Ketiga hal tersebut merupakan elemen pokok value for money namun beberapa pihak berpendapat bahwa tiga elemen saja belum cukup. Perlu ditambah dua elemen lain yaitu keadilan (equity) dan pemerataan atau kesetaraan (equality). Keadilan mengacu pada adanya kesempatan sosialyang sama untuk mendapatkan pelayanan publik yang berkualitas dan kesejahteraan ekonomi. Selain keadilan, perlu dilakukan distribusi secara merata. Artinya penggunaan uang publik hendaknya tidak hanya terkonsentrasi pada kolompok tertentu saja, melainkan dilakukan secara merata (Mardiasmo 2002, 7).

\section{METODE PENELITIAN}

Penelitian dilaksanakan di Badan Pengelolaan Keuangan Dan Aset Daerah kabupaten Bengkalis tahun 2018. Adapun yang menjadi populasi dari penelitian ini adalah staf/aparatur pada kantor Badan Pengelolaan Keuangan dan Aset Daerah Kabupaten Bengkalis sebagai pengelolaan anggaran daerah yaitu berjumlah 153 orang. Inspektorat Kabupaten Bengkalis sebagai pengawasan penyelenggaraan pemerintah daerah berjumlah 45. Dewan Perwakilan Rakyat Daerah Kabupaten Bengkalis sebagai perwakilan partisipasi masyarakat berjumlah 45 orang. Sampel dalam penelitian ini menggunakan proporsional sampling yaitu teknik sampling dapat digunakan pada populasi berstrata, populasi area ataupun populasi cluster, penggunaan perwakilan berimbang. Jadi sampel dalam penelitian ini berjumlah 93 orang dengan menggunakan proporsional sampling, BPKAD 31 orang, Inspektorat 31 orang dan DPRD 31. Adapun teknik pengumpulan data yang digunakan dalam penelitian ini adalah angket atau kuesioner, wawancara, dokumentasi dan studi pustaka. 


\section{HASIL DAN PEMBAHASAN PENELITIAN}

\section{Responden}

Kuesioner yang disebar sebanyak 93 buah kuesioner, yang kembali sebanyak 93 buah, untuk mengetahui latar belakang responden akan disajikan dalam bentuk tabel. Dalam penelitian ini profil responden dibedakan berdasarkan jumlah responden, jenis kelamin, dan pendidikan terakhir.

Tabel 1 Deskripsi Kuesioner Responden

\begin{tabular}{lcc}
\hline \multicolumn{1}{c}{ Keterangan } & Frekuensi & Presentase \\
\hline Kuisioner yang disebarkan & 93 & $100 \%$ \\
Kuisioner yang kembali & 93 & $100 \%$ \\
Kuisioner gugur & 0 & $100 \%$ \\
Kuisioner yang digunakan & 93 & $100 \%$ \\
\hline
\end{tabular}

Jumlah keseluruhan kuesioner yang disebar dalam penelitian ini sebanyak 93 kuesioner. Penyebaran kuesioner dilakukan secara langsung dengan cara menunggu responden saat pengisian kuesioner dan langsung mengumpulkan kusioner yang telah diisi.

\section{Uji Validitas Data}

Perhitungan valid angket pada pengaruh akuntabilitas, partisipasi masyarakat dan pengawasan terhadap kinerja anggaran berkonsep value for money terdiri dari 27 pertanyaan. Dasar pengambilan keputusan, apabila $r_{\text {hitung }}>$ $\mathrm{r}_{\text {tabel }}$ dengan taraf signifikan $\alpha=0,05$ atau $5 \%$ dinyatakan valid.

Tabel 2 Uji Validitas

\begin{tabular}{cccc}
\hline Pertanyaan & $\mathbf{r}_{\text {hitung }}$ & $\mathbf{r}_{\text {tabel }}$ & Keterangan \\
\hline 1 & 0,668 & 0,207 & Valid \\
2 & 0,641 & 0,207 & Valid \\
3 & 0,703 & 0,207 & Valid \\
4 & 0,518 & 0,207 & Valid \\
5 & 0,656 & 0,207 & Valid \\
6 & 0,629 & 0,207 & Valid \\
7 & 0,585 & 0,207 & Valid \\
8 & 0,832 & 0,207 & Valid \\
9 & 0,600 & 0,207 & Valid \\
10 & 0,602 & 0,207 & Valid \\
11 & 0,694 & 0,207 & Valid \\
12 & 0,784 & 0,207 & Valid \\
13 & 0,645 & 0,207 & Valid \\
14 & 0,594 & 0,207 & Valid \\
15 & 0,739 & 0,207 & Valid
\end{tabular}




\begin{tabular}{llll}
16 & 0,832 & 0,207 & Valid \\
17 & 0,768 & 0,207 & Valid \\
18 & 0,585 & 0,207 & Valid \\
19 & 0,832 & 0,207 & Valid \\
20 & 0,600 & 0,207 & Valid \\
21 & 0,602 & 0,207 & Valid \\
22 & 0,629 & 0,207 & Valid \\
23 & 0,629 & 0,207 & Valid \\
24 & 0,524 & 0,207 & Valid \\
25 & 0,490 & 0,207 & Valid \\
26 & 0,595 & 0,207 & Valid \\
27 & 0,490 & 0,207 & Valid \\
\hline
\end{tabular}

Sumber: Data Olahan

Berdasarkan tabel 2 di atas uji validitas yang peneliti lakukan dapat disimpulkan bahwa: seluruh item pernyataan variabel Akuntabilitas (X1), Partisipasi Masyarakat (X2) dan Pengawasan terhadap variabel Kinerja Anggaran berkonsep Value For Money (Y) menunjukan bahwa korelasi product moment lebih besar dari $r_{\text {tabel }}$ sebesar 0,207 dari distribusi $r_{\text {tabel }}$ dengan tingkat signifikan 5\% dan jumlah sampel 93 orang sehingga dapat dikatakan bahwa semua pernyataan pada variabel $\mathrm{X}$ dan $\mathrm{Y}$ dinyatakan valid dan dapat digunakan sebagai untuk penelitian.

\section{Uji Reliabilitas}

\begin{tabular}{cc}
\multicolumn{3}{c}{ Tabel 3 Reliability Statistics } \\
\hline $\begin{array}{c}\text { Cronbach's } \\
\text { Alpha }\end{array}$ & N of Items \\
\hline 954 & 27 \\
\hline Sumber: Output SPSS
\end{tabular}

Berdasarkan tabel 3 di atas, menunjukkan hasil pengujian reliabilitas dilihat dari nilai cronbach's alpha $0,951>0,60$, sehingga dikatakan bahwa seluruh instrumen yang digunakan tersebut reliabel untuk digunakan. Dengan data keseluruhan menggunakan skala reliabilitas jika nilai korelasi cronbach alpha < 0,60 tidak baik (tidak reliabel), 0,6-0,79 dapat diterima (reliabel) dan $\geq 0,80$ baik (reliabel).

\section{Uji Regresi Linier Berganda}

Tabel 4 Uji Regresi Linier Berganda

\begin{tabular}{|c|c|c|c|c|c|}
\hline \multirow[t]{2}{*}{ Model } & \multicolumn{2}{|c|}{$\begin{array}{c}\text { Unstandardized } \\
\text { Coefficients }\end{array}$} & \multirow{2}{*}{$\begin{array}{c}\text { Standardized } \\
\text { Coefficients } \\
\text { Beta }\end{array}$} & \multirow[t]{2}{*}{$T$} & \multirow[t]{2}{*}{ Sig. } \\
\hline & $\boldsymbol{B}$ & Std. Error & & & \\
\hline (Constant) & 3,962 &, 816 & & 4,852 & ,000 \\
\hline Akuntabilitas & ,289 &, 059 & ,239 & 4,940 & ,000 \\
\hline Partisipasi & ,998 &, 075 & ,630 & 13,333 & ,000 \\
\hline $\begin{array}{l}\text { pISSN 2549-3086 } \\
\text { elSSN 2657-1676 }\end{array}$ & & & & & 104 \\
\hline
\end{tabular}




\begin{tabular}{lccccc} 
Pengawasan & 199 &, 055 &, 165 & 3,610 &, 001 \\
\hline a. Dependent Variable: Kinerja Anggaran Berkonsep Value for Money & & & \\
Sumber: Output SPSS
\end{tabular}

Berdasarkan tabel 4 di atas didapat persamaan diatas didapat persamaan regresi linier berganda sebagai berikut: $\mathrm{Y}=\mathrm{a}+\mathrm{b}_{1} \cdot \mathrm{x}_{1}+\mathrm{b}_{2} \cdot \mathrm{x}_{2}+\mathrm{b}_{3} \cdot \mathrm{x}_{3}=$ 5,140+0,356.X1+0,900.X2+0,332.X3, Y = Kinerja Anggaran Berkonsep Value for Money, $\mathrm{a}=$ Nilai Konstan, X1 = Akuntabilitas, X2 = Partisipasi Masyarakat, $\mathrm{X} 3$ = Pengawasan. Dari persamaan regresi tersebut dapat dijabarkan bahwa nilai konstanta (a) sebesar adalah 3,962. Yang artinya apabila jika tidak ada variabel Akuntabilitas, partisipasi dan pengawasan maka kinerja anggaran berkonsep value for money (Y) sebesar 3,962. Nilai koefisien regresi variabel akuntabilitas sebesar 0,289 jika variabel partisipasi dan pengawasan tetap dan setiap penambahan 1 nilai akuntabilitas maka Kinerja Anggaran Berkonsep Value For Money akan mengalami peningkatan sebesar 0,289. Koefisien bernilai positif, artinya terjadi hubungan positif antara akuntabilitas terhadap Kinerja Anggaran Berkonsep Value For Money. Nilai koefisien regresi variabel partisipasi sebesar 0,998 jika variabel pakuntabilitas dan pengawasan tetap dan setiap penambahan 1 nilai partisipasi maka Kinerja Anggaran Berkonsep Value For Money akan mengalami peningkatan sebesar 0,998. Koefisien bernilai positif, artinya terjadi hubungan positif antara partisipasi terhadap Kinerja Anggaran Berkonsep Value For Money. Nilai koefisien regresi variabel pengawasan sebesar 0,199 jika variabel akuntabilitas dan partisipasi tetap dan setiap penambahan 1 nilai akuntabilitas maka Kinerja Anggaran Berkonsep Value For Money akan mengalami peningkatan sebesar 0,199. Koefisien bernilai positif, artinya terjadi hubungan positif antara pengawasan terhadap Kinerja Anggaran Berkonsep Value For Money.

\section{Uji Hipotesis}

Diketahui nilai $\mathrm{t}_{\text {tabel }}$ pada taraf signifikansi $5 \%$ (2-tailed) dan df atau $\mathrm{t}_{\text {tabel }}$ pada rumus $\mathrm{n}-\mathrm{k}$ yaitu: $\mathrm{df}=\mathrm{n}-\mathrm{k} ;$ alpha/2, $=93-3 ; 0,05 / 2,=90 ; 0,025, \mathrm{t}_{\text {tabel }}=1,986$.

Tabel 5 Uji Parsial Akuntatabilitas.

\begin{tabular}{|c|c|c|c|c|c|c|}
\hline & \multirow[t]{2}{*}{ Model } & \multicolumn{2}{|c|}{$\begin{array}{c}\text { Unstandardized } \\
\text { Coefficients }\end{array}$} & \multirow{2}{*}{$\begin{array}{c}\text { Standardized } \\
\text { Coefficients } \\
\text { Beta }\end{array}$} & \multirow[t]{2}{*}{$T$} & \multirow[t]{2}{*}{ Sig. } \\
\hline & & $\boldsymbol{B}$ & Std. Error & & & \\
\hline \multirow[t]{2}{*}{1} & (Constant) & 9,678 & 1,454 & & 6,656 & , 000 \\
\hline & Akuntabilitas & 1,040 &, 064 & ,861 & 16,169 &, 000 \\
\hline
\end{tabular}

Berdasarkan tabel 5 di atas diketahui untuk variabel akuntabilitas (X1) nilai $t_{\text {hitung }}(16,169)>t_{\text {tabel }}(1.986)$ dengan signifikan $(0,000)<(0,05)$. Maka dapat diartikan Ha diterima, dimana variabel akuntabilitas (Xl) berpengaruh terhadap kinerja anggaran berkonsep value for money (Y). Hal ini menunjukan semakin tinggi akuntabilitas maka kinerja anggaran berkonsep value for money semakin meningkat. 
Tabel 6 Uji Parsial Partisipasi Masyarakat

\begin{tabular}{|c|c|c|c|c|c|c|}
\hline & \multirow[t]{2}{*}{ Model } & \multicolumn{2}{|c|}{$\begin{array}{c}\text { Unstandardized } \\
\text { Coefficients }\end{array}$} & \multirow{2}{*}{$\begin{array}{c}\text { Standardized } \\
\text { Coefficients } \\
\text { Beta }\end{array}$} & \multirow[t]{2}{*}{$T$} & \multirow[t]{2}{*}{ Sig. } \\
\hline & & $\boldsymbol{B}$ & Std. Error & & & \\
\hline 1 & (Constant) & 5,678 & 1,025 & & 5,538 & ,000 \\
\hline & Partisipasi & 1,493 & ,056 & 942 & 26,839 & 000 \\
\hline
\end{tabular}

Diketahui untuk variabel partisipasi masyarakat $(X 2)$ nilai $t_{\text {hitung }}(26,839)>$ $\mathrm{t}_{\text {tabel }}(1.986)$ dengan signitikan $(0,000)<(0,05)$ maka Ha diterima, dimana variabel partisipasi masyarakat (X2) berpengaruh terhadap kinerja anggaran berkonsep value for money $(\mathrm{Y})$. Hal ini menunjukan semakin tinggi partisipasi masyarakat maka kinerja anggaran berkonsep value for money semakin meningkat.

Tabel 7 Uji Parsial Pengawasan

\begin{tabular}{|c|c|c|c|c|c|}
\hline \multirow[t]{2}{*}{ Model } & \multicolumn{2}{|c|}{$\begin{array}{c}\text { Unstandardized } \\
\text { Coefficients }\end{array}$} & \multirow{2}{*}{$\begin{array}{c}\text { Standardized } \\
\text { Coefficients } \\
\text { Beta }\end{array}$} & \multirow[t]{2}{*}{$T$} & \multirow[t]{2}{*}{ Sig. } \\
\hline & $\boldsymbol{B}$ & Std. Error & & & \\
\hline 1 (Constant) & 11,470 & 1,568 & & 7,314 &, 000 \\
\hline Pengawasan & ,994 & ,072 & ,823 & 13,846 &, 000 \\
\hline
\end{tabular}

Sumber: Output SPSS

Diketahui untuk variabel pengawasan $(\mathrm{X} 3)$ nilai $\mathrm{t}_{\text {hitung }}(13,846)>\mathrm{t}_{\text {tabel }}$ (1.986) dengan signitikan $(0,000)<(0,05)$. Maka dapat diartikan Ha diterima, dimana variabel pengawasan (X3) berpengaruh terhadap kinerja anggaran berkonsep value for money (Y). Hal ini menunjukan semakin tinggi pengawasan maka kinerja anggaran berkonsep value for money semakin meningkat.

Uji f atau uji simultan, pengujian ini dilakukan untuk menguji secara serentak untuk mengetahui apakah variabel independen yang dimaksud dalam penelitian mempunyai pengaruh terhadap variabel dependen. Peneliti dalam penelitian ini memakai tingkat signifikansi $\alpha 0,05$ atau 5\%. Bila nilai $f_{\text {hitung }}>f_{\text {tabel }}$ maka hipotesis dapat diterima berarti variabel independen berpengaruh terhadap variabel dependen yaitu variabel $\mathrm{X}_{1}, \mathrm{X}_{2}$ dan $\mathrm{X}_{3}$ terhadap $\mathrm{Y}$.

Tabel 8 Uji F Simultan

\begin{tabular}{llccccc}
\hline Model & $\begin{array}{c}\text { Sum of } \\
\text { Squares }\end{array}$ & Df & $\begin{array}{c}\text { Mean } \\
\text { Square }\end{array}$ & F & Sig. \\
\hline 1 & Regression & 1379,937 & 3 & 459,979 & 427,883 &, $000^{\mathrm{b}}$ \\
& Residual & 95,676 & 89 & 1,075 & & \\
& Total & 1475,613 & 92 & & & \\
\hline
\end{tabular}

a. Dependent Variable: Kinerja Anggaran Berkonsep Value for Money

b. Predictors: (Constant), Pengawasan, Partisipasi, Akuntabilitas

Sumber: Output SPSS

Berdasarkan tabel 8 di atas, diperoleh $F_{\text {hitung sebesar 427,883 dengan }}$ menggunakan tingkat signifikan $5 \%(0,05) \mathrm{F}$ tabel dapat diperoleh sebagai berikut: $\operatorname{df}(\mathrm{n} 1)=\mathrm{k}-1=3-1=2, \operatorname{df}(\mathrm{n} 2)=\mathrm{n}-\mathrm{k}=93-3=90$. Berdasarkan tabel $\mathrm{F}$ 
dengan nilai $\mathrm{df}(\mathrm{n} 1) 2$ dan $\mathrm{df}(\mathrm{n} 2)$ 28, taraf signifikan 0,05 maka didapatkan nilai $\mathrm{f}$ tabel adalah sebesar 3,10. Pada tabel 8 di atas $F_{\text {hitung }}>F_{\text {tabel }}(427,883>3,10)$ maka Ha diterima, dengan nilai signifikan sebesar $0,000<0,05$. Artinya adalah variabel Akuntabilitas (X1), partisipasi masyarakat (X2) dan pengawasan (X3) berpengaruh terhadap Kinerja anggaran berkonsep value for money (Y).

\section{Uji Determinasi}

Identifikasi Determinasi $\left(\mathrm{R}^{2}\right)$ berfungsi untuk mengetahui signifikan variabel maka harus dicari koefisien determinan menunjukkan besarnya kontribusi variabel independen terhadap variabel dependen. Semakin besar koefisien determinasi, maka semakin baik kemampuan variabel independen menerangkan variabel dependen (Singgih 200, 150).

Tabel 9 Uji Determinasi

\begin{tabular}{|c|c|c|c|c|}
\hline Model & $\boldsymbol{R}$ & R Square & $\begin{array}{l}\text { Adjusted } R \\
\text { Square }\end{array}$ & $\begin{array}{l}\text { Std. Error of } \\
\text { the Estimate }\end{array}$ \\
\hline 1 &, $967^{\mathrm{a}}$ & ,935 & ,933 & 1,037 \\
\hline
\end{tabular}

Korelasi ganda antara $\mathrm{X}_{1}, \mathrm{X}_{2}$ dan $\mathrm{X}_{3}$ terhadap $\mathrm{Y}$ sebesar 0,933 . Koefisisen determinasi $\left(\mathrm{R}^{2}\right)$ sebesar 0,935 digunakan untuk mengetahui persentase pengaruh variabel independent terhadap perubahan variabel dependent. Artinya Pengaruh Akuntabilitas, Partisipasi dan Pengawasan Terhadap Kinerja Anggaran Berkonsep Value For Money adalah 93,5\%, sedangkan sisanya yaitu 6,5\% (100\%-93,5\%) dipengaruhi atau dijelaskan oleh variabel lain selain variabel independent $\mathrm{X}_{1}, \mathrm{X}_{2}$ dan $\mathrm{X}_{3}$. Standar kesalahan estimasi adalah 1,037. faktor-faktor lain yang belum bisa dijadikan variabel seperti prinsip hukum dan aturan, prinsip transparansi, prinsip responsivitas, prinsip orientasi konsensus, prinsip keadilan dan kewajaran.

\section{KESIMPULAN}

Secara parsial variabel akuntabilitas berpengaruh terhadap kinerja anggaran berkonsep value for money, hal ini menunjukan semakin tinggi akuntabilitas maka kinerja anggaran berkonsep value for money semakin meningkat. Secara parsial variabel partisipasi masyarakat berpengaruh terhadap kinerja anggaran berkonsep value for money, hal ini menunjukan semakin tinggi partisipasi masyarakat maka kinerja anggaran berkonsep value for money semakin meningkat. Secara parsial variabel pengawasan berpengaruh terhadap kinerja anggaran berkonsep value for money, hal ini menunjukan semakin tinggi pengawasan maka kinerja anggaran berkonsep value for money semakin meningkat. Secara silmutan variabel Akuntabilitas, partisipasi masyarakat dan pengawasan berpengaruh terhadap kinerja anggaran berkonsep value for money pada Badan Pengelolaan Keuangan dan Aset Daerah Kabupaten Bengkalis dengan besar pengaruh 93,5\%, dari ketiga variabel yang berpengaruh dominan adalah partisipasi masyarakat. 


\section{DAFTAR PUSTAKA}

Asrida. 2012. "Pengaruh Penerapan Prinsip Akuntabilitas Dan Transparansi Keuangan Terhadap Kinerja Penyusunan Anggaran", Jurnal Kebangsaan $1(1)$.

Bastian, Indra. 2001. Akuntansi Sektor Publik di Indonesia. Yogyakarta: BPFE.

Bastian, Indra. 2005. Akuntansi Sektor Publik Suatu Pengantar. Yogyakarta: Erlangga.

Batubara, Zakaria. 2016. "Pengembangan Sistem Akuntansi Zakat Pada Badan Amil Zakat (BAZ) Dan Lembaga Amil Zakat (LAZ) Di Indonesia". IQTISHADUNA: Jurnal Ilmiah Ekonomi Kita 5 (2), 124-30.

BPKAD. 2016. Rencana Strategis Badan Pengelolaan Keuangan dan Aset Daerah Kabupaten Bengkalis tahun 2016-2021.

Bugin, Burhan. 2013. Metodologi Peneltian Sosial dan Ekonomi. Jakarta: Kencana.

Dwiyanto, Agus. 2005. Mewujudkan Good Governance Melai Pelayanan Publik. Yogyakarta: Gajah Mada University Press.

Eko, Sutoro. 2005. Pembaharuan Otonomi Daerah. Yogyakarta: APMD Press.

Ferina, Ika Sasti dan Fika Arista. 2013. "Penilaian Kinerja dengan Menerapkan Indikator Value For Money" Jurnal Manajemen dan Bisnis Sriwijaya 11 (2).

Hamidi. 2010. Metodologi penelitian dan Teori Komunikasi. Malang: UMM Press.

Handoko, Hani. 2009. Manajemen Edisi 2. Yogyakarta: BPFE.

Hendarsyah, Decky. 2016. "Penggunaan Uang Elektronik Dan Uang Virtual Sebagai Pengganti Uang Tunai Di Indonesia". IQTISHADUNA: Jurnal Ilmiah Ekonomi Kita 5 (1), 1-15.

Horngren, Charles dkk. 2016. Pengantar Akuntansi Manajemen. Jakarta: Erlangga.

Irianto, Agus. 2004. Statistik: Konsep Dasar dan Aplikasinya. Jakarta: Prenada Media.

Ishak, Khodijah. 2018. "The Role of Islamic Finance In Economic Development". IQTISHADUNA: Jurnal Ilmiah Ekonomi Kita 7 (2), 131143.

Iswahyudi, Aries, Iwan Triyuwono dan M. Achsin. 2016. "Hubungan Pemahaman Akuntabilitas, Transparansi, Partisipasi, Value For Money Dan Good Governance". Jurnal Ilmiah Akuntansi 1 (2).

Junery, Muhammad Fadhil, and Norhanisah Norhanisah. 2018. "Pengaruh Anggaran Berbasis Kinerja Terhadap Peningkatan Kinerja Aparatur Pemerintah Daerah". JAS (Jurnal Akuntansi Syariah) 2 (1), 142-150.

Kementrian Dalam Negeri Republik Indonesia. 2013. Peraturan Menteri Dalam Negeri Republik Indonesia Nomor 64 Tahun 2013 Tentang Penerapan Standar Akuntansi Pemerintahan Berbasis Akrual.

Mardiasmo. 2002. Akuntansi Sektor Publik. Yogyakarta: Andi.

Mardiasmo. 2004. Otonomi dan Manajemen Keuangan Daerah. Yogyakarta: Andi.

Muri, Yusuf. 2014. Metodologi Penelitian Kuantitatif, Kualitatif dan Penelitian Gabungan. Jakarta: Prenadamedia Group. 
Noor, Juliansyah. 2011. Metodologi penelitian Skripsi, Tesis, Disertasi dan Karya Ilmiah. Jakarta: Kencana Prenada Media Group.

Pertiwi, Debi Putri. 2015. "Pengaruh Akuntabilitas, Transparansi, dan Pengawasan Terhadap Pengelolaan Anggaran Berkonsep Value For Money", JOM FEKON 2 (2).

Pratisto, Arif. 2004. Cara Mudah Mengatasi Masalah Statistik dan Rancangan Percobaan dengan SPPSS 12. Jakarta: PT. Elex Media Kompotindo.

Prasetio, Primadi. 2017. "Pengaruh Partisipasi Anggaran Terhadap Kinerja Manajerial Dengan Job Relevant Information (JRI) Dan Komitmen Organisasi Sebagai Variabel Intervening”. JAS (Jurnal Akuntansi Syariah) 1 (1), 151-169.

Rahman. 2005. Kamus Besar Bahasa Indonesia. Jakarta: Trimedia.

Rudianto. 2013. Akuntansi Manajemen, Informasi untuk Pengambilan Keputusan Strategis. Jakarta: Erlangga.

Sarwono, Jonathan. 2015. Rumus-Rumus Populer dalam SPSS 22 Riset Skripsi. Yogyakarta: CV. Andi Offset.

Sabeni, Arifin dan Imam Ghozali. 2008. Pokok-pokok Akuntansi Pemerintahan. Yogyakarta: BPFE Yogyakarta.

Singgih, Santoso. 2000. Spss. Jakarta: PT. Elex Media Kompotindo.

Siregar, Baldric. 2015. Akuntansi Sektor Publik: Akuntansi Keuangan Pemerintah Daerah Berbasis Akrual. Yogyakarta: Sekolah Tinggi Ilmu Manajemen YKPN.

Siregar, Syofian. 2010. Statistika Deskriptif untuk Penelitian: Dilengkapi Perhitungan Manual dan Aplikasi SPSS Versi 17. Jakarta: PT RajaGrafindo Persada.

Siregar, Syofian. 2013. Metodologi penelitian Kuantitatif. Jakarta: Kencana.

Somantri, Ating dan Sambas Ali Mahidin. 2006. Aplikasi Statistika dalam Penelitian. Bandung: CV. Pustaka Setia.

Sugiyono. 2012. Metode Penelitian Kombinasi. Bandung: Alfabeta.

Sugiyono. 2017. Metode Penelitian Kuantitatif, Kualitatif, dan R\&D. Bandung: Alfabet.

Sujarweni, Wiratna. 2015. Statistik Untuk Bisnis dan Ekonomi. Yogyakarta: Pustaka Baru Press.

Supramono dan Intiyas Utami. 2004. Desain Proposal Penelitian. Yogyakarta: Andi.

Syafri, Wirman. 2012. Studi Tentang Administrasi Publik. Jakarta: Erlangga.

Tanjung, Chaidir Anwar. 2018. Penyidikan Korupsi Bansos Rp 277 M di Bengkalis Masuki Jilid II. Diakses dari: https://news.detik.com/berita/d3893168/penyidikan-korupsi-bansos-rp-277-m-di-bengkalis-masuki-jilidii, tanggal 1 Mei 2018.

Ulum, Ihyaul. 2004. Akuntansi Sektor Publik: sebuah pengantar. Malang: Universitas Muhammadiyah Malang.

Ulum, Ihyaul. 2009. Audit Sektor Publik: Suatu Pengantar. Jakarta: PT Bumi Aksara.

Utami, Kurnia. 2013. "Pengaruh Pengetahuan Dewan Tentang Anggaran Terhadap Pengawasan Keuangan Daerah dengan Variabel Pemoderasi Partisipasi Masyarakat dan Transparansi Kebijakan Publik". Jurnal WRA 1 (1).

Waluyo. 2007. Manajemen Publik. Bandung: Mandar Maju. 